\title{
Problemy europeizacji polityki energetycznej Niemiec
}

\section{Wstęp}

W ramach procesu integracji europejskiej polityka energetyczna zajmuje szczególne miejsce, chociażby ze względu na fakt, iż traktat z Lizbony nadał współpracy w sektorze energii podstawy prawno-traktatowe. Polityka energetyczna stała się dziedziną kompetencji dzielonych między Unią Europejską a państwami członkowskimi, a Komisja Europejska uzyskała - ograniczone - prawo inicjatywy w tej dziedzinie. Chociaż wspólnotowa polityka energetyczna została zapoczątkowana w 1952 roku w ramach Europejskiej Wspólnoty Węgla i Stali oraz w Europejskiej Wspólnocie Energii Atomowej, ustanowionej traktatem podpisanym w Rzymie 25 marca 1957 roku, to jednak przełom w europeizacji sektora energetycznego przyniósł Jednolity Akt Europejski z 1986 roku, a wraz z nim inicjatywa wspólnego rynku. Natomiast od lat 90 . XX wieku rosło zaangażowanie Unii Europejskiej w politykę energetyczną w kontekście deregulacji i budowy wspólnego rynku oraz rozwijania odnawialnych źródeł energii, istotnych także dla polityki ochrony środowiska i klimatu.

Celem niniejszego opracowania jest syntetyczne przedstawienie problematyki europeizacji polityki energetycznej Niemiec na przełomie XX i XXI wieku. Analiza obejmuje kwestię dostosowania niemieckiego ustawodawstwa do unijnych regulacji w ramach procesu liberalizacji i tworzenia rynku wewnętrznego energii UE z uwzględnieniem postępowań prowadzonych przez Komisję Europejską zarówno wobec Niemiec, jak i niemieckich koncernów energetycznych oraz problem wspierania rozwoju odnawialnych źródeł energii w Niemczech w kontekście unijnych rozwiązań. Analiza opiera się na dostępnych źródłach i literaturze przedmiotu, jak również badaniach własnych Autorki ${ }^{1}$.

1 Niniejszy tekst powstał $\mathrm{w}$ ramach realizacji zadania badawczego nr WPAiSM/ DS/17/2015 pt. Niemcy w procesie uwspólnotowienia polityki energetycznej Unii 


\section{Istota i mechanizmy europeizacji}

Termin „europeizacja” pojawił się w latach 90. w debacie o skutkach procesu integracji europejskiej dla państw członkowskich Unii Europejskiej. Odnosi się on do zmian wewnątrz państw członkowskich będących skutkiem integracji europejskiej i wynikających stąd konsekwencji dla zachowań państw członkowskich $\mathrm{w}$ ramach systemu wielopoziomowego. Stąd też zasadniczym przedmiotem analizy stały się zróżnicowane przejawy europeizacji w państwach narodowych będące skutkiem ich członkostwa w UE. Pojęcie „europeizacja” jest przy tym stosowane do określenia skuteczności polityk podejmowanych na poziomie UE, jak również adaptacji do procesów integracyjnych mechanizmów, procesów i instytucji polityk państw członkowskich (następuje ona od szczebla europejskiego do narodowego, tj. „z góry do dołu", top-down). Punktem wyjścia są negocjacje międzyrządowe, w efekcie których tworzone są instytucje na poziomie UE, a na końcu znajdują się rezultaty dostosowania państw członkowskich. Według tego ujęcia integracja stanowi warunek europeizacji. Innymi słowy bez integracji nie byłoby europeizacji. Dla części badaczy europeizacja jest przede wszystkim „rezultatem”, a rzadko "procesem”, w związku z czym pojawia się kwestia stopnia oddziaływania na państwa członkowskie. Podstawę analizy procesu europeizacji stanowi wytworzenie i rozwój specyficznych „struktur zarządzania” na płaszczyźnie UE. Oznacza to, że „coś” musi się najpierw dokonać na poziomie UE, aby można było oczekiwać skutków na płaszczyźnie narodowej, co może być równoznaczne z tworzeniem nowych instytucji, sieci politycznych czy też określonym postrzeganiem problemu i jego przepracowaniem w państwie członkowskim.

Europeizacja może być rozumiana jako proces, w efekcie którego polityki narodowe są w coraz większym stopniu kształtowane przez politykę europejską ${ }^{2}$. Natomiast Robert Ladrech definiuje europeizację jako „stopniowy proces reorientacji kierunku i kształtu polityki krajowej w taki sposób, że polityczna i gospodarcza dynamika UE staje się częścią organizacyjnej logiki krajowej polityki

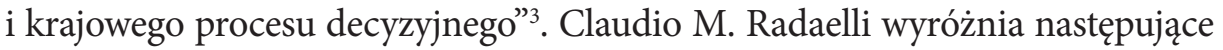

Europejskiej, finansowanego w ramach działalności statutowej Wydziału Prawa, Administracji i Stosunków Międzynarodowych Krakowskiej Akademii im. Andrzeja Frycza Modrzewskiego.

2 T. Börzel, Institutional Adaptation to Europeanization in Germany and Spain, „Journal of Common Market Studies" 1999, t. 37, nr 4, s. 573-574.

3 R. Ladrech, Europeanization of Domestics Politics and Institutions: The case of France, „Journal of Common Market Studies” 1994, t. 32, nr 1, s. 69. 
składowe europeizacji: a) konstrukcja, b) dyfuzja, c) instytucjonalizacja formalnych i nieformalnych zasad, procedur, modeli polityk i stylów, poglądów oraz norm, które są najpierw definiowane i łączone w procesie politycznym w UE, a następnie włączane w logikę dyskursu wewnątrzpaństwowego, struktur politycznych i polityk publicznych ${ }^{4}$. Według Radaelliego europeizacja odzwierciedla wpływ polityki europejskiej na logikę procesów politycznych w państwach członkowskich. Przedmiotem europeizacji stają się struktury polityczne, polityki publiczne (łącznie $\mathrm{z}$ ich instrumentami), jak również struktury kognitywno-normatywne - normy i wartości. Procesy europeizacji mogą prowadzić do adaptacji polityk narodowych do europejskich wytycznych bądź do ich zasadniczych przekształceń (transformacji). Możliwy jest również brak zmian w państwach członkowskich względnie odejście od rozwiązań europejskich ${ }^{5}$. Europeizacja nie oznacza konwergencji ani harmonizacji polityk narodowych i ich instrumentów - są one skutkami procesu europeizacji ${ }^{6}$.

Jak słusznie zauważa Agnieszka K. Cianciara, w praktyce europeizacja w UE „ma charakter dwukierunkowy i interakcyjny, a analityczne rozróżnienie na europeizację odgórną (top-down) i oddolną (bottom-up) ulega zatarciu”. Wynika to z faktu, że „reguły i normy definiowane na poziomie unijnym, ulegają następnie dyfuzji na poziomie krajowym, są bowiem konstruowane przy udziale krajowych aktorów". Innymi słowy, aktorzy z państw członkowskich przenoszą na poziom unijny określone preferencje, strategie i sposoby działania, współkształtując tym samym unijne reguły i normy ${ }^{7}$.

Dokonuje się rozróżnienia między pionowymi (wertykalnymi) i poziomymi (horyzontalnymi) mechanizmami europeizacji. O ile pionowe mechanizmy europeizacji (hierarchiczny stosunek UE i państw członkowskich) działają niejako w ramach formalnego przymusu dostosowania, o tyle mechanizmy poziome - poprzez ustalanie pierwotnie dyskursywnych ram dla rozwijania określonych mechanizmów rynkowych i procesów politycznych. Pionowe mechanizmy europeizacji są stosowane w obszarze integracji pozytywnej (harmonizowanie, koordynowanie) i negatywnej (eliminacja barier, deregulacja, liberalizacja). Integracja pozytywna jest związana $\mathrm{z}$ działaniami zmierzającymi do harmonizacji, unifikacji lub koordynacji przepisów obowiązujących

4 C.M. Radaelli, The Europeanization of Public Policy, [w:] K. Featherstone, C.M. Radaelli (red.), The Politics of Europeanization, Oxford 2003, s. 30.

5 Tamże, s. 37.

6 C.M. Radaelli, Whither Europeanization? Concept stretching and substantive change, „European Integration on-line papers” 2000, t. 4, nr 8, s. 5.

7 A.K. Cianciara, Wzory europeizacji zewnętrznej: mechanizmy, uwarunkowania, rezultaty, „Studia Europejskie” 2013, nr 3, s. 12. 
w państwach członkowskich. W przypadku integracji negatywnej chodzi o usuwanie ograniczeń konkurencji i handlu, rozwinięcie mechanizmów rynkowych, czy też inicjowanie konkurencji na rynku wewnętrznym.

Europeizacja instrumentów polityk państw członkowskich UE może się odbywać za pomocą poziomych mechanizmów, które wpływają na narodowe procesy polityczne poprzez normy i wartości, jak również poprzez postrzeganie problemu i formułowanie określonych rozwiązań politycznych. C. Radaelli wskazuje w związku z tym na dyrektywy o "charakterze minimalistycznym" (harmonizacja tylko w takim zakresie, w jakim wymaga tego dyrektywa), jak również procesy regulacyjne i programy działania, które funkcjonują jako dodatkowe podstawy legitymizacji narodowych procesów politycznych ${ }^{8}$. Konwergencja instrumentów polityk narodowych może dodatkowo zostać wzmocniona przez formułowanie i dyfuzję wspólnych paradygmatów polityki czy też formułowanie stosownych wytycznych dotyczących europejskiego modelu polityk i ich instrumentów.

W literaturze przedmiotu powszechne jest pojęcie niedostosowania („misfit”) reguł poziomu krajowego do reguł poziomu europejskiego, za pomocą którego wyjaśniania się procesy adaptacji w państwach członkowskich UE. Im niższy poziom dostosowania struktur państw członkowskich do unijnych, tym większe prawdopodobieństwo zmiany. Adaptacja nie jest jednak automatyczna, impulsy europeizacji są bowiem przekształcane przez aktorów i instytucje państw członkowskich, przy czym czynnikiem rozstrzygającym jest presja dostosowania wewnątrz systemu politycznego. Przymus prawny jest głównym mechanizmem europeizacji w państwach członkowskich UE. Są one zobowiązane do wdrożenia prawa unijnego do krajowych porządków prawnych. Efektywność europeizacji jest zapewniona przez środki dyscyplinujące Komisji Europejskiej i Trybunału Sprawiedliwości Unii Europejskiej.

Ze względu na specyficzne czynniki wewnętrzne (polityczne, gospodarcze, społeczne itp.) europeizacja przynosi w poszczególnych państwach zróżnicowane rezultaty. Wyróżnia się następujące typy rezultatów procesu europeizacji: 1) inercja (inertia; no change) - oznacza brak zmian wynikający z pasywnego sprzeciwu wobec europeizacji;

2) opór przed zmianami (retrenchment; resistance to change) - oznacza brak zmian wynikający z aktywnego sprzeciwu wobec europeizacji;

3) absorpcja (absorption; low degree of change) - oznacza nieznaczne dostosowanie i modyfikacje, które jednak nie wpływają w sposób istotny na logikę instytucjonalną oraz praktykę działania;

8 C.M. Radaelli, The Europeanization..., s. 43. 
4) transformacja (transformation; substantial change) - oznacza fundamentalną zmianę logiki instytucjonalnej i praktyki działania.

Podkreśla się, że procesy europeizacji przebiegają odmiennie $\mathrm{w}$ państwach członkowskich, jednakże kluczowy pozostaje mechanizm koercyjny, w „którym wyższy stopień niedostosowania środowiska krajowego do unijnego oznacza większą presję europeizacji i większy zakres zmian”"

\section{Europeizacja polityki energetycznej Niemiec w kontekście liberalizacji rynku energii elektrycznej i gazu ziemnego}

Proces liberalizacji rynku energii energii elektrycznej i gazu w UE został zainicjowany na początku lat 90 . XX wieku wraz z przedstawieniem przez Komisję 22 stycznia 1992 roku tzw. pierwszego pakietu energetycznego, który ostatecznie jako dyrektywa 96/92/WE (elektroenergetyczna, której celem było stworzenie podstaw prawnych do stopniowego tworzenia konkurencyjnego i niedyskryminującego rynku elektroenergetycznego $)^{10}$ oraz dyrektywa 98/30/WE (gazowa, której celem było stworzenie konkurencyjnego rynku gazu ziemnego) ${ }^{11}$ został włączony do prawa wspólnotowego. Zastosowane rozwiązania prawne okazały się w praktyce niewystarczające. W celu pogłębienia liberalizacji sektora w 2003 roku przyjęto tzw. drugi pakiet energetyczny: rozporządzenie (WE) nr 1228/2003 w sprawie warunków dostępu do sieci elektroenergetycznej ${ }^{12}$, dyrektywę 2003/54/WE (elektroenergetyczną) ${ }^{13}$ i dyrektywę 2003/55/WE (gazową) ${ }^{14}$. Pomijając szereg kwestii szczegółowych, należy nadmienić, że drugi pakiet poruszał przede wszystkim

$9 \quad$ A.K. Cianciara, $d z$. cyt., s. 28.

10 Dyrektywa 96/92/WE Parlamentu Europejskiego i Rady z dnia 19 grudnia 1996 r. dotycząca wspólnych zasad rynku wewnętrznego energii elektrycznej (Dz. Urz. WE L 27 z 30.01.1997).

11 Dyrektywa 98/30/WE Parlamentu Europejskiego i Rady z dnia 22 czerwca 1998 r. dotycząca wspólnych zasad w odniesieniu do rynku wewnętrznego gazu ziemnego (Dz. Urz. WE L 204 z 21.07.1998).

12 Rozporzadzenie (WE) nr 1228/2003 Parlamentu Europejskiego i Rady z dnia 26 czerwca 2003 r. w sprawie warunków dostępu do sieci w odniesieniu do transgranicznej wymiany energii elektrycznej (Dz. Urz. UE L 176 z 15.07.2003).

13 Dyrektywa 2003/54/WE Parlamentu Europejskiego i Rady z dnia 26 czerwca 2003 r. dotycząca wspólnych zasad rynku wewnętrznego energii elektrycznej i uchylająca dyrektywę 96/92/WE (Dz. Urz. UE L 176 z 15.07.2003).

14 Dyrektywa 2003/55/WE Parlamentu Europejskiego i Rady z dnia 26 czerwca 2003 r. dotyczaca wspólnych zasad rynku wewnętrznego gazu ziemnego i uchylająca dyrektywę 98/30/WE (Dz. Urz. UE L 176 z 15.07.2003, s. 57). 
takie kwestie jak wyznaczanie operatorów systemów przesyłowych i ich zadania, dalszy rozdział przedsiębiorstw zintegrowanych pionowo, zasady poufności, ochrony środowiska oraz kwestie techniczne. Celem zapewnienia efektywniejszego funkcjonowania wewnętrznego rynku energii przyjęto rozwiązania zawarte $\mathrm{w}$ tzw. trzecim pakiecie energetycznym, który składa się z następujących aktów prawnych: dyrektywy Parlamentu Europejskiego i Rady 2009/72/WE z dnia 13 lipca 2009 roku dotyczącej wspólnych zasad rynku wewnętrznego energii elektrycznej i uchylającej dyrektywę 2003/54/ $W^{15}$, dyrektywy Parlamentu Europejskiego i Rady 2009/73/WE z dnia 13 lipca 2009 roku dotyczącej wspólnych zasad rynku wewnętrznego gazu ziemnego i uchylającej dyrektywę 2003/55/WE ${ }^{16}$, rozporządzenia Parlamentu Europejskiego i Rady (WE) nr 713/2009 z dnia 13 lipca 2009 roku ustanawiającego Agencję ds. Współpracy Organów Regulacji Energetyki ${ }^{17}$, rozporządzenia Parlamentu Europejskiego i Rady (WE) nr 714/2009 z dnia 13 lipca 2009 roku w sprawie warunków dostępu do sieci w odniesieniu do transgranicznej wymiany energii elektrycznej i uchylającego rozporządzenie (WE) nr 1228/2003 ${ }^{18}$; rozporządzenia Parlamentu Europejskiego i Rady (WE) nr 715/2009 z dnia 13 lipca 2009 roku w sprawie warunków dostępu do sieci przesyłowych gazu ziemnego i uchylającego rozporządzenie (WE) nr 1775/2005 ${ }^{19}$. Państwa członkowskie musiały transponować dyrektywy do 3 marca 2011 roku, jak również zapewnić skuteczność przepisów dotyczących rozdziału przesyłu od produkcji i dostaw od 3 marca 2012 roku (z wyjątkiem regulacji, które pozwalają państwu członkowskiemu odmówić certyfikacji operatorów systemów przesyłowych z państw trzecich, jeśli nie spełniają oni wymagań dotyczących rozdziału i mogą stwarzać zagrożenie dla bezpieczeństwa dostaw energii w danym państwie członkowskim i w Unii Europejskiej - termin transpozycji tych przepisów to 3 marca 2013 roku).

Otwarcie rynku energii w Niemczech postępowało wskutek dostosowania ustawodawstwa do unijnych regulacji dotyczących wewnętrznego rynku energii ${ }^{20}$. Ustawa o gospodarce energetycznej (Gesetz über

\footnotetext{
Dz. Urz. UE L 211 z 14.08.2009, s. 55.

Dz. Urz. UE L 211 z 14.08.2009, s. 94.

Dz. Urz. UE L 211 z 14.08.2009, s. 1.

Dz. Urz. UE L 211 z 14.08.2009, s. 15.

Dz. Urz. UE L 211 z 14.08.2009, s. 36.

20 Szerzej: M. Heuterkes, M. Janssen (red.), Die Regulierung von Gas- und Strommärkten in Deutschland, Westfälische Wilhelms-Universität Münster, „Beiträge aus der angewandten Wirtschaftsforschung” 2008, nr 29; T. Renz, Vom Monopol zum Wettbewerb. Die Liberalisierung der deutschen Stromwirtschaft, Opladen 2001; N. Angenendt,
} 
die Elektrizitäts- und Gasversorgung, Energiewirschaftsgesetz - EnGW) z 24 kwietnia 1998 roku stworzyła konieczne warunki prawne służące przełamaniu dotychczasowego monopolu i umożliwieniu konkurencji w sektorze energetycznym. W odniesieniu do sektora gazu ziemnego ustawa była niewystarczająca. Co więcej, liberalizacja i deregulacja niemieckiego rynku gazu nie była jej przedmiotem. Wprawdzie ustawa zawierała także zapisy, które generalnie obowiązywały przedsiębiorstwa zaopatrzenia energetycznego, jednakże przepisy, które miały znaczenie dla powstania konkurencji, dotyczyły wyłącznie przedsiębiorstw operujących na rynku energii elektrycznej. Niemniej jednak otwarcie rynku gazu ziemnego w Niemczech następowało stopniowo, niejako równolegle do rynku energii elektrycznej. Nie bez znaczenia w tym kontekście były zapisy 6 . noweli ustawy przeciwko ograniczaniu konkurencji (Gesetz gegen Wettbewerbsbeschränkungen - GWB), która weszła w życie 1 stycznia 1999 roku, w szczególności zakaz tworzenia karteli (Kartellverbot) i nadużywania dominującej pozycji na rynku. Mimo że po 2003 roku oficjalnie rynek gazu w Niemczech był uznany za otwarty, zmiany - inaczej niż w sektorze elektroenergetycznym - zachodziły dość wolno. Wśród przyczyn wymienia się brak optymalnych zasad systemu dostępu do sieci przesyłowych w ramach dobrowolnych porozumień partnerów rynkowych (tzw. Verbändevereinbarungen - VV), ograniczoną dostępność gazu ziemnego i koncentrację dużych złóż surowca w relatywnie niewielu regionach świata.

Ustawa o gospodarce energetycznej z 1998 roku stworzyła warunki ramowe dla wspomnianych wyżej dobrowolnych porozumień partnerów rynkowych - w odniesieniu do wolnego od dyskryminacji dostępu do istniejących sieci przesyłowych. Pierwsze porozumienie, które ustalało warunki dostępu do sieci w odniesieniu do gazu ziemnego, Bundesverband der Deutschen Industrie (BDI), Bundesverband der Deutschen Gas- und Wasserwirtschaft (BGW), Verband kommunaler Unternehmen (VKU) i Verband der Industriellen Energie- und Kraftwirtschaft (VIK) zawarły 4 lipca 2000 roku. Z kolei 15 marca 2001 roku podjęto decyzję o uzupełnieniu tego porozumienia

Unbundling im internationalen Vergleich: Rechtliche Entwicklungen in Deutschland im Zuge der Liberalisierung des Strombinnenmarktes im Vergleich zu Österreich (Studien zur Rechtswissenschaft), Hamburg 2007; C. Kreis, Deregulierung und Liberalisierung der europäischen Elektrizitätswirtschaft: theoretische und empirische Befunde, Baden-Baden 2004; S. Twelemann, Stromwirtschaft im Spannungsfeld zwischen Wettbewerb und Klimapolitik. Eine Untersuchung am Beispiel des deutschen Strommarktes, Frankfurt am Main [u.a.] 2006. 
(1. Nachtrag) m.in. o regulacje dotyczące transparentności i rozwoju w dostępie do sieci, komercyjnego dostępu do magazynów i zarządzania tzw. „wąskimi gardłami”. Natomiast aneks z 21 września 2001 roku (2. Nachtrag) zawierał zapisy dotyczące technicznych warunków ramowych przy dostępie do sieci, utworzenia Rady Arbitrażowej (Schiedsstelle) i zastosowania profilu obciążenia dla małych konsumentów gazu ziemnego. Kolejnym krokiem na drodze do osiągnięcia liberalizacji rynku gazu ziemnego w Niemczech było porozumienie z dnia 3 maja 2002 roku (VV Gas II). Najważniejsza zmiana dotyczyła połączenia istniejących wówczas trzech poziomów dystrybucji surowca w dwa (w odniesieniu do kształtowania cen za transport, ujednolicony system opłat dla regionalnej i ponadregionalnej dystrybucji gazu ${ }^{21}$.

Podobne porozumienia były zawierane w sektorze elektroenergetycznym. Porozumienie VV I zawarte 22 maja 1998 roku przez BDI, VIK i VDEW (Verband der Elektrizitätswirtschaft e. V.) zawierało kryteria określające opłaty za dostęp do sieci przesyłowej. Z kolei porozumienie z 13 grudnia 1999 roku (Zweite Verbändevereinbarung, VV Strom II) ${ }^{22}$ dotyczyło eksploatacji sieci elektroenergetycznej, weszło w życie 1 stycznia roku 2000 i miało obowiązywać przez dwa lata. Zrezygnowano z podziału niemieckiego rynku energii elektrycznej na dwie strefy handlowe (północ i południe). Natomiast porozumienie z 13 grudnia 2001 roku (Verbändevereinbarung II plus; VV II plus) ${ }^{23}$, po wejściu w życie 1 stycznia 2002 roku (było ograniczone do dwóch lat) stworzyło instrumenty służące lepszemu porównaniu cen za eksploatację sieci elektroenergetycznej. Poza tym uprościło procedurę zmiany dostawcy dla prywatnych klientów i ułatwiło handel energią elektryczną w perspektywie krótkoterminowej ${ }^{24}$.

W ustawie o gospodarce energetycznej pominięto kwestie utworzenia urzędu regulacji oraz nadzór nad rozwojem struktury rynku. W efekcie powstał oligopol wielkich koncernów energetycznych, które podzieliły się rynkiem energii elektrycznej i gazu ziemnego, a tym samym zdominowały niemiecki rynek energetyczny.

Kolejnym krokiem w kierunku liberalizacji niemieckiego rynku energii była pierwsza nowelizacja ustawy o gospodarce energetycznej z 20 maja

${ }^{21}$ Zob. szerzej: H.-W. Schiffer, Energiemarkt Deutschland, 9. völlig neu bearb. Aufl., Köln 2005.

22 Zawarte przez BDI, VIK, VDEW, DVG (Deutsche Verbundgesellschaft e.V.), ARE (Arbeitsgemeinschaft regionaler Energieversorgungs-Unternehmen) i VKU.

23 Zawarte przez BDI, VIK, VDEW, VDN (Verband der Netzbetreiber e. V.), ARE i VKU.

24 S. Twelemann, dz. cyt., s. 50-51. 
2003 roku. Jej celem było uzupełnienie istniejących ram prawnych dla sektora gazu ziemnego. Dotyczyły one przede wszystkim prawa dostępu do sieci, definicji sieci, jak i eksploatacji sieci, w tym także publikacji zasadniczych warunków dostępu do sieci i rozdzielenia sprawozdawczości finansowej. Druga nowelizacja ustawy o gospodarce energetycznej z 12 lipca 2005 roku miała natomiast na celu dostosowanie istniejących ram prawnych dla energii elektrycznej i sektora gazu ziemnego do unijnych dyrektyw z 2003 roku $^{25}$. Główne punkty ustawy dotyczyły m.in. prawnego rozdziału od pozostałych form aktywności przedsiębiorstw energetycznych, regulacji sieci zaopatrzenia, która powinna zapewnić wolny od dyskryminacji dostęp do sieci w sektorach gazu i energii elektrycznej oraz stworzenia urzędu regulacji rynku energii elektrycznej i gazu ziemnego - Bundesnetzagentur für Elektrizität, Gas, Telekommunikation, Post und Eisenbahn, w miejsce dotychczasowego Urzędu Regulacji Telekomunikacji i Poczty (Regulierungsbehörd für Telekommunikation und Post). Natomiast nowelizacja ustawy z sierpnia 2011 roku służyła transpozycji trzeciego pakietu liberalizacyjnego i dotyczyła takich kwestii jak rynek i konkurencja, w tym rozdział sieci transportowej (trzy modele w sektorach elektroenergetycznym i gazu ziemnego: rozdział własnościowy; niezależny operator systemu, ISO; niezależny operator przesyłowy, ITO), procedura certyfikacji dla administratorów sieci transportowej przez Bundesnetzagentur, dostęp do magazynów gazu ziemnego; plany rozwoju sieci przesyłowej; zmienne taryfy i wspieranie inteligentnych systemów pomiaru oraz wzmocnienie praw konsumentów.

Szczegółowe regulacje dotyczące warunków dostępu do sieci elektroenergetycznej i gazu ziemnego oraz opłat za dostęp do nich zostały zawarte w rozporządzeniach Verordnung über den Zugang zu Elektrizitätsversorgung (Stromnetzzugangsverordnung - StromNZV), Verordnung über den Zugang zu Gasversorgungsnetzen (Gasnetzzugangsverordnung - GasNZV), Verordnung über die Entgelte für den Zugang zu Elektrizitätsversorgung (Stromnetzentgeltverordnung - StromNEV) i Verordnung über die Entgelte für den Zugang zu Gasversorgungsnetzen (Gasnetzentgeltverordnung - GasNEV) z 25 lipca 2005 roku. Opierały się one na ustawie o gospodarce energetycznej z 2005 roku i zastąpiły dotychczasowe dobrowolne porozumienia zawierane przez partnerów rynkowych - związki i zrzeszenia. W tym miejscu warto nadmienić, że wytyczne w zakresie dalszej liberalizacji rynku gazu ziemnego rząd federalny przedstawił 19 maja 2010 roku. Celem było zwiększenie konkurencyjności, doprowadzenie do obniżki cen „błękitnego paliwa”,

25 Zob. szerzej: T. Olbricht, Netzzugang in der deutschen Gaswirtschaft, Essen 2008. 
w szczególności zaś ułatwienie nowym przedsiębiorcom wejścia na rynek ${ }^{26}$. 18 sierpnia 2010 roku rząd federalny uchwalił rozporządzenie (Gasnetzzugangsverordnung $)^{27}$, którego istota sprowadza się do redukcji liczby obszarów rynkowych (Marktgebiet), wewnątrz których dostawcy gazu mogą działać bez ograniczeń, z sześciu do maksymalnie dwóch do 2013 roku, udogodnień $\mathrm{w}$ dostępie do ograniczonych możliwości transportowych (Transportkapazität) oraz ułatwień przy podłączaniu nowych elektrowni gazowych do sieci. Rozporządzenie weszło w życie 9 września 2010 roku. Proces implementacji dyrektyw w Niemczech był przedmiotem postępowań Komisji Europejskiej.

Komisja Europejska wszczęła postępowanie przeciw Niemcom z powodu spóźnionego i niezadowalającego wdrożenia dyrektywy 98/30/WE na podstawie art. 226 Traktatu ustanawiającego Wspólnotę Europejską (TWE) ${ }^{28}$. Po upływie terminu jej wdrożenia, w sierpniu 2000 roku, Komisja Europejska zajęła krytyczne stanowisko wobec wybranego przez ustawodawcę niemieckiego modelu procedury dostępu do sieci poprzez dobrowolne porozumienia. Krytyka dotyczyła także niewystarczającej transpozycji zapisów dotyczących rozdziału i oddzielnej sprawozdawczości finansowej zintegrowanych przedsiębiorstw sektora gazu ziemnego. Komisja Europejska doszła do wniosku, że niemiecki reżim prawny nie może zapewnić wolnego od dyskryminacji i uczciwego dostępu nowych oferentów do sieci gazu ziemnego. W październiku 2000 roku Komisja Europejska rozpoczęła postępowanie przeciw Niemcom z powodu niewystarczającego wdrożenia dyrektyw - w szczególności braku niezależnego urzędu regulacji i przepisów dotyczących rozdziału

26 Paradigmenwechsel für mehr Wettbewerb auf dem Gasmarkt: Bundeskabinett beschließt Neufassung der Gasnetzzugangsverordnung, 19. Mai 2010, Pressemitteilung, Bundesministerium für Wirtschaft und Technologie, http://www.bmwi.de/BMWi/ Navigation/Presse/pressemitteilungen,did=343128.html (dostęp: 04.06.2016).

27 Bundesregierung macht mit der neuen Gasnetzzugangsverordnung den Weg für mehr Wettbewerb auf dem Gasmarkt frei, 18. August 2010, Pressemitteilung, Bundesministerium für Wirtschaft und Technologie, http://www.bmwi.de/BMWi/Navigation/ Presse/pressemitteilungen,did=355136.html (dostęp: 04.06.2016).

28 Art. 226: „Jeśli Komisja uzna, że Państwo Członkowskie uchybiło jednemu z zobowiązań, które na nim ciążą na mocy niniejszego Traktatu, wydaje ona uzasadnioną opinię w tym przedmiocie, po uprzednim umożliwieniu temu Państwu przedstawienia swych uwag. Jeśli Państwo to nie zastosuje się do opinii w terminie określonym przez Komisję, może ona wnieść sprawę do Trybunału Sprawiedliwości”, Traktat ustanawiający Wspólnotę Europejską (TWE), Dz. Urz. UE 2006 C 321E, http://eur -lex.europa.eu/legal-content/PL/TXT/PDF/?uri=CELEX:C2006/321E/01\&from=PL (dostęp: 10.06.2016). 
(pierwsze pismo napominające). Drugie pismo Komisji Europejskiej uzasadniające stanowisko zostało przekazane rządowi federalnemu w czerwcu 2001 roku. Niemcy dostały dwa miesiące na wyeliminowanie punktów, których dotyczyła krytyka Komisji Europejskiej. Ostatecznie 16 października 2002 roku Komisja zdecydowała o pozwaniu Niemiec do Trybunału. Orzeczeniem z 1 kwietnia 2004 roku Trybunał stwierdził spóźnioną implementację dyrektywy 98/30/WE29. Także po upływie terminu transpozycji drugiego pakietu energetycznego w lipcu 2004 roku Komisja Europejska już w październiku 2004 roku wszczęła postępowanie przeciw Niemcom o naruszenie art. 226 TWE. W marcu 2005 roku przesłała Niemcom pismo prezentujące stanowisko uzupełnione o powody rozpoczęcia postępowania. Niemcy musiały w krótkim czasie znowelizować ustawę o gospodarce energetycznej, aby uniknąć pozwu do Trybunału.

Na koniec należy odnotować, że w czerwcu 2010 roku Komisja Europejska wszczęła postępowania przeciwko 20 państwom członkowskim w związ$\mathrm{ku}$ z naruszeniem zobowiązań na rynku energii elektrycznej i gazu ziemnego. W przypadku Niemiec w odniesieniu do sektora energii elektrycznej największe wątpliwości dotyczyły niezgodnego $\mathrm{z}$ wymaganiami regulacji unijnych zarządzania przepływem, braku wspólnej skoordynowanej metody zarządzania przepływem, nierespektowania przez operatorów systemu przesyłowego w pełni wymagań przejrzystości regulacji (np. wymogu publikowania wszystkich istotnych danych dotyczących handlu ponadgranicznego). W odniesieniu do sektora gazu ziemnego krytyka dotyczyła braku zaaprobowania przez kompetentne władze istotnych punktów systemu przesyłu ${ }^{30}$.

Wprawdzie rynek energii elektrycznej i gazu ziemnego w Niemczech podlegał sukcesywnym zmianom, jednak liberalizacja sektora energetycznego (energii elektrycznej i gazu ziemnego) natrafiała na liczne trudności i ograniczenia. Wśród wielu barier wymienić należy przede wszystkim brak konkurencji związany z dominującą pozycją przedsiębiorstw energetycznych i niewystarczający rozdział skonsolidowanych podmiotów, zwłaszcza na poziomie dystrybucji, jak również porozumienia między koncernami energetycznymi niezgodne ze wspólnym rynkiem ${ }^{31}$, czego przykładem jest zawarta przez francuski Gaz de

29 Urteil des EuGH vom 01.04.2004, C-64/03, https:/www.jusmeum.de/urteil/eugh/ 2c9acc05efccbb5e5384d2a419531e3ed6f9c277d7d4b70b9b7de62b5ad20e35? page =2 (dostęp: 12.06.2016).

30 Pressemitteilung der Kommisssion vom 24. Juni 2010, MEMO/10/275.

31 Szerzej: M. Hofman, Regulierung und Wettbewerb. Koordinationsmechanismen im europäischen Energiesektor, Zürich 2013. 
France i niemiecki E.ON umowa o wspólnej eksploatacji rurociągu MEGAL, którym przez Czechy i Austrię przesyłany jest do UE rosyjski gaz ${ }^{32}$.

18 lipca 2007 roku Komisja wszczęła postępowanie kartelowe przeciwko koncernowi E.ON AG i jego spółce-córce E.ON Ruhrgas AG, jak również GDF Suez Sa z powodu naruszenia art. 101 ust. 1 Traktatu o funkcjonowaniu Unii Europejskiej (TFUE). Zgodnie z art. 101 ust. 1 TFUE, niezgodne ze wspólnym rynkiem i zakazane są wszelkie porozumienia między przedsiębiorstwami, wszelkie decyzje związków przedsiębiorstw i wszelkie praktyki uzgodnione, które mogą wpływać na handel między państwami członkowskimi, a których celem lub skutkiem jest zapobieżenie, ograniczenie lub zakłócenie konkurencji rynku wewnętrznego. Podstawą badania przez Komisję było porozumienie między E.ON i GDF Suez dotyczące izolacji narodowego rynku w związku z planowaną budową gazociągu MEGAL w 1975 roku. Strony porozumiały się dodatkowo, że GDF Suez nie będzie sprzedawał gazu transportowanego tym rurociągiem w Niemczech, a E.ON we Francji. Pomimo stopniowej liberalizacji rynków energii strony nie odstępowały od dodatkowego porozumienia z 1975 roku. Porozumienie o podziale rynku było utrzymywane przynajmniej do 2005 roku. Według KE oba koncerny odwlekały tym porozumieniem osiągnięcie przez swoich klientów korzyści, jakie wiązały się z wdrożeniem dyrektywy z 1998 roku, tj. silniejszej konkurencji cenowej i większego wyboru dostawców surowca. Komisja stwierdziła, że porozumienie to nie sprzyjało konkurencji, a wręcz ją ograniczało (art. 101 ust. 1 TFUE) ${ }^{33}$. Decyzją z 8 lipca 2009 roku Komisja stwierdziła naruszenie art. 101 ust. 1 TFUE i zobowiązała E.ON oraz GDF Suez zgodnie z art. 7 Rozporzadzenia Rady (WE) nr 1/2003 z dnia 16 grudnia 2002 roku w sprawie wprowadzenia $w \dot{z} y$ cie regut konkurencji ustanowionych $w$ art. 81 i 82 Trakta$t u^{34}$ do zaprzestania tego naruszenia. Zgodnie $\mathrm{z}$ art. 23 ust. 2 Rozporządzenia Rady (WE) nr 1/2003, Komisja nałożyła grzywnę w wysokości 1,106 mld euro (po 553 mln euro E.ON/E.ON Ruhrgas i GDF Suez). Komisja stwierdziła, że porozumienie o podziale rynku zalicza się do najpoważniejszych naruszeń art. 101 TFUE. Dotyczyło ono całości surowca z rurociągu MEGAL, a tym samym zasadniczej części wspólnego rynku ${ }^{35}$. Zarówno E.ON, jak i GDF Suez

\footnotetext{
32 Informacja prasowa Komisji z 12 czerwca 2008 r., IP/08/394.

33 Kommission, Entscheidung vom 8. Juli 2009, Sache COMP/39.401 - E.ON/GDF.

34 Rozporzadzenie Rady (WE) $n r$ 1/2003 z dnia 16 grudnia 2002 r. w sprawie wprowadzenia $w$ życie regut konkurencji ustanowionych $w$ art. 81 i 82 Traktatu, http://eur-lex. europa.eu/legal-content/PL/ALL/?uri=CELEX:32003R0001 (dostęp: 18.06.2016).

35 Pressemitteilung der Kommisssion vom 8. Juli 2009, IP/09/1099.
} 
18 września 2009 roku wniosły pozew do Trybunału o unieważnienie decyzji Komisji (art. 263 TFUE). W orzeczeniu z 29 czerwca 2012 roku Trybunał potwierdził stanowisko Komisji Europejskiej. Niemniej jednak stwierdził, że Komisja przy ustalaniu okresu naruszenia art. 101 TFUE popełniła dwa błędy. Po pierwsze, Komisja nie przedstawiła w odniesieniu do niemieckiego rynku gazu, na którym dopuszczalne były wówczas umowy o demarkacji i umowy koncesji, dowodu, że w okresie od 1980 roku do 1998 roku powstała potencjalna konkurencja, która mogłaby być zakłócona przez porozumienie dotyczące MEGAL. Po drugie, Komisja nie przedstawiła w odniesieniu do rynku francuskiego danych, że naruszenie trwało bezpośrednio po porozumieniu MEGAL z sierpnia 2004 roku, w którym strony potwierdziły, że dodatkowe porozumienie uważają od dłuższego czasu za nieważne. Trybunał uznał decyzję Komisji w tym punkcie za bezpodstawną. Ostatecznie Trybunał określił wysokość kary pieniężnej po $320 \mathrm{mln}$ euro dla E.ON i GDF Suez ${ }^{36}$.

Jako przykłady postępowań dotyczących nadużywania przez przedsiębiorstwa pozycji dominującej na wspólnym rynku można wskazać działania podjęte w stosunku do koncernów RWE i E.ON.

W art. 102 TFUE zawarto zakaz nadużywania przez jedno lub większą liczbę przedsiębiorstw pozycji dominującej na wspólnym rynku lub na znacznej jego części w zakresie, w jakim może to wpływać na handel między państwami członkowskimi. W artykule tym ujęto niezamknięty katalog praktyk będących przejawem zakazanego nadużywania pozycji dominującej. Nadużywanie takie może polegać w szczególności na: a) narzucaniu w sposób bezpośredni lub pośredni niesłusznych cen zakupu lub sprzedaży albo innych niesłusznych warunków transakcji, b) ograniczaniu produkcji, rynków lub rozwoju technicznego ze szkodą dla konsumentów, c) stosowaniu wobec partnerów handlowych nierównych warunków do świadczeń równoważnych i stwarzaniu im przez to niekorzystnych warunków konkurencji, d) uzależnianiu zawarcia kontraktów od przyjęcia przez partnerów zobowiązań dodatkowych.

20 kwietnia 2007 roku Komisja Europejska wszczęła postępowanie w sprawie przedsiębiorstwa RWE, działającego na rynku gazu ziemnego z powodu podejrzenia izolacji rynku gazowego w Północnej Nadrenii-Westfalii poprzez utrudnienie konkurentom dostępu do sieci przesyłowej gazu ziemnego RWE ${ }^{37}$. Zdaniem Komisji, RWE (przedsiębiorstwo zintegrowane

36 EuG, Urteil vom 29. Juni 2012, Rs. T- 360/09 - E.ON/Ruhrgas und E.ON/Kommission; EuG, Urteil vom 29. Juni 2012, Rs. T-370/09 - GDF Suez/Kommission, https:// dejure.org/dienste/vernetzung/rechtsprechung?Text=T-370/09 (dostęp: 15.06.2016).

37 Pressemitteilung der Kommisssion vom 11. Mai 2007, MEMO/07/186. 
pionowo), właściciel spółek zarządzających sieciami przesyłowymi, dopuszczał się praktyk, w wyniku których wyeliminowani byli z niemieckiego rynku energii elektrycznej potencjalni konkurenci RWE. Komisja podejrzewała kontrolowaną przez RWE spółkę zarządzającą sieciami przesyłowymi RWE Transportnetz Gas GmbH o utrudnianie do nich dostępu (RWE zarezerwowała długoterminowo całą przepustowość sieci przesyłowych), zawyżanie opłat za ich wykorzystanie oraz niepodejmowanie działań na rzecz zwiększenia mocy przesyłowych. Ten sposób postępowania wskazywał - według Komisji - na zamierzoną strategię wykluczenia stron trzecich przy przesyle, utrudniał wejście na rynek nowych dostawców. Poprzez wszczęcie postępowania przeciwko RWE Komisja zamierzała doprowadzić do wydania decyzji nakazującej przedsiębiorstwu rozdział własnościowy, polegający na nakazie wyzbycia się posiadanych przez nie sieci, grożąc przy tym RWE wysoką karą pieniężną. W wyniku prowadzonego postępowania RWE zobowiązała się do sprzedaży posiadanych sieci przesyłowych, zamierzając skupić się na samej tylko działalności w zakresie dostaw energii. W wyniku prowadzonego postępowania RWE zobowiązała się w maju 2008 roku do sprzedaży swojej zachodnioniemieckiej sieci przesyłowej gazu ziemnego niezależnemu podmiotowi ${ }^{38}$. Zgodnie z art. 9 Rozporządzenia Rady (WE) nr 1/2003 Komisja zaakceptowała zobowiązanie złożone przez RWE, wydając decyzję z dnia 18 marca 2009 roku $^{39}$. RWE zobowiązała się do sprzedaży całej swojej sieci przesyłowej gazu (około 4 tys. km) w Niemczech. Nabywcą został australijski bank inwestycyjny Macquarie.

Analogiczne działania Komisja podjęła względem koncernu E.ON. W 2006 roku Komisja Europejska wszczęła postępowanie wyjaśniające na niemieckim rynku energii elektrycznej w ramach czynności związanych z badaniem sektorowym ${ }^{40}$. W trakcie postępowania wyjaśniającego Komisja doszła do wniosku, że E.ON mógł nadużyć swojej pozycji dominującej na rynku na dwa sposoby: po pierwsze jako hurtownik na rynku energii elektrycznej poprzez strategiczne ograniczanie zdolności produkcyjnych niektórych elektrowni na rynku hurtowym w celu podbicia ceny, przy czym dodatkowo Komisja miała obawy, że spółka E.ON opracowała i wdrożyła strategię mającą na celu zniechęcenie osób trzecich do inwestowania w produkcję energii; po drugie jako operator systemu przesyłowego poprzez uprzywilejowanie

38 Pressemitteilung der Kommisssion vom 31. Mai 2008, MEMO/08/355.

39 Kommission, Entscheidung vom 18. März 2009, Sache COMP/39.402 - Gasmarktabschottung durch RWE.

40 MEMO/06/483, 12. Dezember 2006. 
własnej produkcji na wtórnym rynku bilansującym energii elektrycznej ${ }^{41}$. W czerwcu 2008 roku E.ON zobowiązał się do sprzedaży posiadanych przez siebie sieci przesyłowych a 26 listopada 2008 roku Komisja przyjęła decyzję (zgodnie z art. 9 Rozporządzenia Rady (WE) nr 1/2003) w sprawie zobowiązań, na podstawie której mocy wiążącej nabrały zobowiązania zaproponowane przez E.ON ${ }^{42}$. Ostatecznie 10 listopada 2009 roku E.ON podpisał umowę sprzedaży elektroenergetycznej sieci przesyłowej z holenderskim państwowym koncernem TenneT.

W przypadku koncernów RWE i E.ON, będących właścicielami sieci i faworyzujących własne spółki przy udzielaniu dostępu do sieci, Komisja Europejska poprzez podjęcie przeciwko nim postępowań doprowadziła do ich podziału.

Warto nadmienić, że koncern Vattenfall bez nacisków Komisji Europejskiej podjął 25 lipca 2008 roku decyzję o sprzedaży elektroenergetycznych sieci przesyłowych, obejmujących całe wschodnie Niemcy. Koncern uznał, że sprzedaż sieci będzie dla niego korzystniejsza, zanim dojdzie do odebrania firmom energetycznym kontroli nad przesyłem. W połowie marca 2010 roku koncern podpisał umowę sprzedaży elektroenergetycznej sieci przesyłowej konsorcjum składającemu się z belgijskiego operatora przesyłowego Elia (60\% udziałów) i australijskiego funduszu inwestycyjnego IMF (40\%).

Natomiast 22 grudnia 2009 roku Komisja wszczęła postępowanie o nadużywanie pozycji na rynku przez E.ON AG, największego sprzedawcę gazu ziemnego w Niemczech, który zaopatrywał regionalne i lokalne przedsiębiorstwa dystrybucji, odbiorców przemysłowych i elektrownie. Komisja zarzuciła koncernowi, że rezerwował znaczną część ciągłych, swobodnie przydzielanych zdolności przesyłowych na punktach wejścia do swojej sieci przesyłowej, co mogło uniemożliwić konkurencyjnym przedsiębiorstwom przesył gazu ziemnego poprzez sieć E.ON do podłączonych do niej odbiorców, a tym samym wykorzystywał swoją dominującą pozycję na rynku (art. 102 TFUE). Komisja stwierdziła, że E.ON posiadał dominującą pozycję zarówno na rynku przesyłu gazu w zakresie sieci gazu niskokalorycznego (typu L) oraz odpowiedniego obszaru rynku gazu wysokokalorycznego (typu $\mathrm{H}$ ), jak również na rynkach dostaw dla klientów przemysłowych i dostaw innych dystrybutorów. 4 maja 2010 roku Komisja ogłosiła decyzję zgodnie z art. 9 Rozporządzenia Rady (WE) nr 1/2003, na podstawie której zobowiązanie E.ON stało się prawnie wiążące. E.ON zobowiązał się bowiem

\footnotetext{
MEMO/08/396, 12. Juni 2008.

42 Pressemitteilung der Kommisssion vom 26. November 2008, IP/08/1774.
} 
uwolnić do października 2010 roku ciągłe, swobodnie przydzielane zdolności przesyłowe na punktach wejścia do swojej sieci $(10 \mathrm{Gwh} / \mathrm{h}$ w przypadku H-gazu, 7,8 Gwh/h - L-gazu), przy czym około 15\% mocy przesyłowych miało być oddane do dyspozycji natychmiast. Dodatkowo E.ON zobowiązał się, że do października 2015 roku zmniejszy w dalszym stopniu swój ogólny udział w rezerwacjach ciągłych, swobodnie przydzielanych zdolności przesyłowych na punktach wejścia: w odniesieniu do rynku gazu typu $\mathrm{H}$ (NetConnect Germany) - do 50\%, zaś w odniesieniu do sieci gazu typu L - do $64 \%{ }^{43}$. Zawarta ugoda miała zakończyć dochodzenie o nadużywanie przez E.ON dominującej pozycji rynkowej w Niemczech i ułatwić działanie konkurencji.

\section{Europeizacja polityki energetycznej Niemiec a wsparcie rozwoju odnawialnych źródeł energii}

Zwiększenie wykorzystania energii produkowanej ze źródeł odnawialnych w Unii Europejskiej zaczęło zyskiwać na znaczeniu w lat 90. ubiegłego wieku. Rozwijanie energetyki odnawialnej ma zwiększyć bezpieczeństwo zaopatrzenia energetycznego, ograniczyć emisję gazów cieplarnianych i zwiększyć konkurencyjność UE w gospodarce światowej. Podejmowane działania na rzecz promocji odnawialnych źródeł energii obejmują zobowiązania państw członkowskich i różne formy zachęty dla podmiotów wykorzystujących odnawialne źródła energii. W 1997 roku został przyjęty dokument Energia dla przyszłości: odnawialne źródła energii. Biała księga strategii wspólnotowej i plan działan ${ }^{44}$, a następnie rozpoczęto prace mające na celu osiągnięcie do 2010 roku 12\% udziału energii ze źródeł odnawialnych w zużyciu energii brutto w UE. Dyrektywa 2001/77/WE Parlamentu Europejskiego i Rady z dnia 27 września 2001 roku w sprawie wspierania produkcji na rynku wewnętrznym energii elektrycznej wytwarzanej ze źródeł odnawialnych zakładała osiągnięcie w UE $22 \%$ udziału energii elektrycznej ze źródeł odnawialnych do 2010 roku $^{45}$. W 2003 roku dyrektywa o biopaliwach (2003/30/WE) nałożyła na państwa członkowskie obowiązek udziału 5,75\% odnawialnych źródeł energii w sektorze transportu, w 2009 roku udział ten podniesiono

43 Kommission, Entscheidung vom 4. Mai 2010, Sache COMP/39.317 - E.ON Gas, http://eur-lex.europa.eu/legal-content/DE/TXT/?uri=CELEX\%3A52010XC1015(01) (dostęp: 19.06.2016). COM (1997) 599 final.

45 Niemcy zostały zobowiązane do zwiększenia udziału odnawialnych źródeł energii w produkcji energii elektrycznej do 12,5\% w 2010 roku. 
do 10\% do 2020 roku. Pomijając kwestie szczegółowe, warto nadmienić, że cele dotyczące zwiększenia wykorzystania odnawialnych źródeł energii zostały skonkretyzowane w komunikacie Komisji do Rady Europejskiej i Parlamentu Europejskiego - Europejska Polityka Energetyczna ${ }^{46} \mathrm{z}$ dnia 10 stycznia 2007 roku. W komunikacie podkreślono, że celem jest osiągnięcie przez UE do 2020 roku 20\% udziału odnawialnych źródeł energii w ogólnym zużyciu energii, 20\% redukcji emisji gazów cieplarnianych w stosunku do poziomu z 1990 roku i 20\% oszczędności zużycia energii. Na posiedzeniu Rady Europejskiej 8-9 marca 2007 roku potwierdzono m.in. zobowiązanie do rozwoju energii ze źródeł odnawialnych po roku 2010. Rada poparła obowiązkowy cel przewidujący $20 \%$ udział energii ze źródeł odnawialnych w całkowitym zużyciu energii do 2020 roku i obowiązkowy minimalny cel przewidujący $10 \%$ udział biopaliw w ogólnym zużyciu benzyny i oleju napędowego w transporcie, który wszystkie państwa członkowskie są zobowiązane osiągnąć do $2020 \mathrm{roku}^{47}$. Z kolei 23 stycznia 2008 roku Komisja Europejska przedstawiła pakiet propozycji dotyczących polityki energetyczno-klimatycznej UE. Celem tego pakietu było obniżenie emisji gazów cieplarnianych w UE o 20\%, wzrost udziału energii ze źródeł odnawialnych w łącznym zużyciu energii o $20 \%$ oraz zwiększenie efektywności energetycznej o $20 \%$ do 2020 roku Ostatecznie w ramach tzw. pakietu energetyczno-klimatycznego przyjęta została m.in. dyrektywa Parlamentu Europejskiego i Rady 2009/28/WE z dnia 23 kwietnia 2009 roku w sprawie promowania stosowania energii ze źródel odnawialnych zmieniajaca i w nastęstwie uchylajaca dyrektywy 2001/77/WE oraz 2003/30/WE ${ }^{48}$. Celem dyrektywy było ustanowienie wspólnych ram dla promowania energii ze źródeł odnawialnych poprzez określenie obowiązkowych krajowych celów ogólnych.

24 lutego 2011 roku Bundestag uchwalił ustawę Europarechtsanpassungsgesetz Erneuerbare Energien ${ }^{49}$, która służyła wdrożeniu dyrektywy 2009/28/WE w sprawie promowania stosowania energii ze źródeł odnawialnych i wprowadzała zmiany do ustawy o odnawialnych źródłach energii (Erneuerbare-Energien-Gesetz, EEG), ustawy o odnawialnych źródłach energii w sektorze energii cieplnej (Erneuerbare-Energien-Wärmegesetz, EEWärmeG),

46 $\operatorname{COM}(2007) 1$ final.

47 Rada Europejska w Brukseli 8-9 marca 2007 r., Konkluzje prezydencji, Bruksela, 9 marca 2007 r., http://www.pga.org.pl/prawo/konkluzje-prezydencji.pdf (dostęp: 14.06.2016).

48 Dz. Urz. UE L 140/16-62 z 05.06.2009.

49 Gesetz zur Umsetzung der Richtlinie 2009/28/EG zur Förderung der Nutzung von Energie aus erneuerbaren Quellen, vom 12. April 2011, BGBl. 2011, cz. 1, nr 17, s. 619. 
w Energiestatistikgesetz, w Baugesetzbuch, w Hochbaustatistikgesetz i rozporządzenia Biomassestrom-Nachhaltigkeitsverordnung. Zgodnie $\mathrm{z}$ art. 4 dyrektywy 2009/28/WE, rząd federalny 4 sierpnia 2010 roku przyjął narodowy plan działania w zakresie odnawialnych energii (Nationaler Aktionsplan für erneuerbare Energie) ${ }^{50}$, którego celem jest osiągnięcie do 2020 roku 18\% udziału energii odnawialnej w końcowym zużyciu energii. W planie działania rząd federalny określił instrumenty służące wsparciu rozbudowy odnawialnych źródeł energii oraz bezpieczeństwu zaopatrzenia, ochrony klimatu, konkurencyjności i innowacyjności, jak też tworzeniu miejsc pracy. Rząd federalny założył, że do 2020 roku udział odnawialnych źródeł energii w zużyciu energii końcowej brutto wyniesie 19,6\%. W odniesieniu do poszczególnych sektorów udziały przedstawiają się następująco: $15,5 \%$ w sektorach grzewczym i chłodzenia, $38,6 \%$ w sektorze energii elektrycznej i 13,2\% w sektorze transportu. Ponadto zawarte zostały przykładowe regionalne i lokalne środki, które mają służyć zrealizowaniu celu, w szczególności zaś krajowe i lokalne organy administracyjne muszą uwzględniać przy planowaniu infrastruktury miejskiej systemy grzewcze i chłodzące wykorzystujące energię ze źródeł odnawialnych. Co więcej, zgodnie z wymogami dyrektywy, od dnia 1 stycznia 2012 roku nowe i istniejące budynki publiczne poddawane generalnemu remontowi na szczeblu krajowym, regionalnym i lokalnym odgrywają rolę wzorców do naśladowania, przez zezwolenie przykładowo na wykorzystanie dachów budynków publicznych lub publiczno-prywatnych przez stronę trzecią do instalacji urządzeń wytwarzających energię ze źródeł odnawialnych.

Rozwój odnawialnych źródeł energii w Niemczech odbywa się nie tylko w ramach polityki energetycznej Unii Europejskiej, lecz jest najważniejszym elementem niemieckiej transformacji energetycznej (Energiewende) obok ograniczenia emisji gazów cieplarnianych i zwiększenia efektywności energetycznej. Energiewende została zapoczątkowana przyjęciem przez rząd federalny jesienią 2010 roku strategii energetycznej do 2050 roku (Energiekonzept für eine umweltschonende, zuverlässige und bezahlbare Energieversorgung) ${ }^{51}$, a następnie uchwaleniem w czerwcu 2011 roku pakietu ustaw, których celem było przyspieszenie realizacji tej strategii

50 Nationaler Aktionsplan für erneuerbare Energie gemäss der Richtlinie 2009/28/EG zur Förderung der Nutzung von Energie aus erneuerbaren Quellen, http://gesetzgebung.beck.de/ sites/gesetzgebung.beck.de/files/nationaler_aktionsplan_ee.pdf (dostęp: 10.06.2016).

51 Energiekonzept für eine umweltschonende, zuverlässige und bezahlbare Energieversorgung, 28.09.2010, http://www.bundesregierung.de/Content/DE/_Anlagen/2012/02/ energiekonzept-final.pdf?__blob=publicationFile (dostęp: 28.06.2016). 
w kontekście podjęcia decyzji o rezygnacji z użytkowania energii jądrowej (kilka miesięcy po awarii elektrowni jądrowej w Japonii) do roku 2022. Szczegółowe zapisy przyjętego latem 2011 roku pakietu energetycznego służyć mają realizacji głównych założeń koncepcji energetycznej rządu federalnego z 2010 roku, w tym:

- zwiększenia udziału energii elektrycznej wyprodukowanej ze źródeł odnawialnych w zużyciu energii elektrycznej brutto do $80 \%$ do roku 2050. Zgodnie z nowelizacją ustawy o energii odnawialnej (Erneuerbare-Energien-Gesetz, EEG) z 2012 roku udział energii elektrycznej wyprodukowanej ze źródeł odnawialnych w zużyciu energii elektrycznej brutto ma systematycznie wzrastać do 35\% w 2020 roku i do $80 \%$ w 2050 roku (50\% w 2030 roku, 65\% w 2040 roku). Natomiast nowelizacja ustawy z 2014 roku ustanowiła dodatkowe cele pośrednie: udział ten powinien wzrosnąć do 40-45\% do 2025 roku, a w 2035 roku wynieść 55-60\%;

- zwiększeniu udziału odnawialnych źródeł energii w zużyciu energii końcowej brutto do $18 \%$ w 2020 roku, 30\% do 2030 roku, $45 \%$ do 2040 roku i $60 \%$ do $2050 \mathrm{roku}^{52}$.

Warto nadmienić, że koncepcja polityki energetycznej do 2050 roku była poprzedzona Zasadniczymi punktami zintegrowanego programu energetycznego i klimatycznego (Eckpunkte für ein integriertes Energie- und Klimapro-

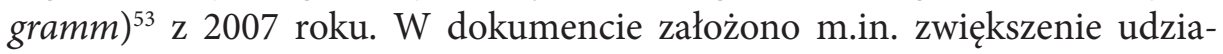
łu odnawialnych źródeł energii w produkcji energii elektrycznej brutto do 2020 roku do $25-30 \%$ i w produkcji ciepła do $14 \%$. Natomiast wzrost udziału biogazu do $10 \%$ miał przyczynić się do redukcji zależności Niemiec od importu gazu ziemnego.

Państwa członkowskie UE mogą stosować różne mechanizmy wsparcia rodzimych źródeł energii odnawialnej, w tym system zielonych certyfikatów, ulgi podatkowe, jak również pomoc bezpośrednią dla producentów roślin energetycznych służących produkcji biokomponentów.

W RFN do 1990 roku operatorzy niezależnych instalacji do produkcji energii elektrycznej posiadali prawo - opierające się na regulacjach antykartelowych - doprowadzania energii elektrycznej wytworzonej ze źródeł odnawialnych do sieci publicznych przedsiębiorstw zaopatrzenia energetycznego.

52 Szerzej: B. Molo, Polityka bezpieczeństwa energetycznego Niemiec w XXI wieku, Kraków 2013.

53 Eckpunkte für ein integriertes Energie- und Klimaprogramm, http://www.bmwi.de/ $\mathrm{BMWi}$ /Redaktion/PDF/E/eckpunkt-fuer-ein-integriertes-energie-und-klimaprogramm,property=pdf,bereich=bmwi2012,sprache=de,rwb=true.pdf (dostęp: 22.06.2016). 
W oparciu o porozumienie zawarte w sierpniu 1979 roku przez Verband der Elektrizitätswirtschaft (VDEW), VIK i BDI, operatorzy instalacji uzyskali możliwość otrzymania zwrotu poniesionych nakładów w formie rekompensaty. Porozumienie nie było jednak prawnie wiążące ${ }^{54}$, stąd też konieczne stało się prawne uregulowanie kwestii doprowadzania do sieci energii elektrycznej wyprodukowanej ze źródeł odnawialnych i stosownej rekompensaty.

Ustawa o doprowadzeniu energii elektrycznej ze źródeł odnawialnych do sieci (Stromeinspeisungsgesetz) ${ }^{55}$ z 7 grudnia 1990 roku (weszła w życie 1 stycznia 1991 roku) zobowiązywała przedsiębiorstwa zaopatrzenia elektroenergetycznego do odbierania energii elektrycznej pozyskanej z wody, wiatru, energii słonecznej, gazu wysypiskowego (Deponiegas), gazu gnilnego (Klärgas) i biomasy oraz zapewniała gwarantowaną cenę na energię elektryczną produkowaną ze źródeł odnawialnych. Skutkowała ona znaczącym wzrostem inwestycji w turbiny wiatrowe oraz biogazownie. Ponadto energetyka słoneczna została wsparta przez program „1000 słonecznych dachów” (1000-Dächer-Programm).

Ustawa o pierwszeństwie odnawialnych źródeł energii (Gesetz für den Vorrang Erneuerbarer Energien) ${ }^{56}$ z 29 marca 2000 roku zastąpiła wspomnianą ustawę o doprowadzeniu energii elektrycznej ze źródeł odnawialnych do sieci i poszerzyła zakres wsparcia o energię geotermalną. Ustawa zakładała, że energia elektryczna wyprodukowana ze źródeł odnawialnych ma pierwszeństwo w dostępie do sieci, a producent sprzedaje ją za cenę gwarantowaną (feed-in-tariff). Fotowoltaika otrzymała dodatkowe wsparcie poprzez program „100 tys. słonecznych dachów” (100.000 Dächer-Solarstrom-Programm). Nowelizacja ustawy w 2004 roku była spowodowana koniecznością wdrożenia dyrektywy 2001/77WW ${ }^{57}$ i zaleceń raportu z 2002 roku (EEG-Erfahrungsbericht 2002). Podczas gdy ustawa z 2000 roku zawierała jedynie zapis o podwojeniu udziału odnawialnych źródeł energii w zużyciu energii końcowej do 2010 roku, nowelizacja z 2004 roku zawierała cel zwiększenia udziału odnawialnych źródeł energii w zaopatrzeniu w energię elektryczną

54 E. Reschke, Das Erneuerbare-Energien-Gesetz (EEG) und das europäische Beihilferecht, Marburg 2014, s. 26.

55 Gesetz über die Einspeisung von Strom aus erneuerbaren Energien in das öffentliche Netz vom 7. Dezember 1990 (Stromeinspeisungsgesetz), BGBI., cz. I, s. 2633.

56 Erneuerbare-Energien-Gesetz vom 29. März 2000, BGBI., cz. I, s. 305.

57 Dyrektywa 2001/77/WE Parlamentu Europejskiego i Rady z dnia 27 września 2001 r. w sprawie wspierania produkcji na rynku wewnętrznym energii elektrycznej wytwarzanej ze źródeł odnawialnych, http://orka.sejm.gov.pl/Drektywy.nsf/all/32001L0077/\%24File/32001L0077.pdf (dostęp: 17.06.2016). 
do 2010 roku do $12,5 \%$, a do 2020 roku do $20 \%$. Z kolei nowelizacja ustawy z 2009 roku zawierała po raz pierwszy obok taryfy gwarantowanej regulację dotyczącą bezpośredniego wprowadzenia na rynek energii elektrycznej wyprodukowanej ze źródeł odnawialnych, na podstawie której operatorzy instalacji mogliby energię elektryczną wyprodukowaną ze źródeł odnawialnych samodzielnie sprzedawać stronie trzeciej. Natomiast celem nowelizacji ustawy z 2012 roku było zapewnienie zrównoważonego rozwoju zaopatrzenia energetycznego, które zmniejsza jego koszty i służy wsparciu dalszego rozwoju technologii do produkcji energii elektrycznej ze źródeł odnawialnych. Jako warte wsparcia zostały wymienione: energia wodna, energia wiatru, energia promieniowania słonecznego, energia geotermalna i biomasa (łącznie $\mathrm{z}$ biogazem, biometanem, gazem wysypiskowym i gnilnym). Obok taryfy gwarantowanej znowelizowana ustawa zawierała zapisy o premii rynkowej za bezpośrednie urynkowienie energii elektrycznej pochodzącej ze źródeł odnawialnych. Zostało ono zdefiniowane jako sprzedaż energii elektrycznej wyprodukowanej ze źródeł odnawialnych przez operatorów instalacji albo dystrybutorów na giełdzie energii elektrycznej lub rynkach OTC. W procesie urynkowienia powstają dla operatorów instalacji dodatkowe koszty, których nie ponoszą operatorzy instalacji korzystający z modelu taryfy gwarantowanej. W związku z tym ustawa przewidywała stosowną premię (Managementprämie). Natomiast nowelizacja ustawy z końca czerwca 2012 roku dotycząca fotowoltaiki (Gesetz zur Änderung des Rahmens für Strom aus solarer Strahlungsenergie und zu weiteren Änderungen im Recht der erneuerbaren Energien) wprowadziła szereg zmian w odniesieniu do wynagrodzenia za energię elektryczną produkowaną $\mathrm{z}$ instalacji promieniowania słonecznego oraz ustanowiła roczny limit na budowę nowych instalacji fotowoltaicznych na poziomie 2,5 do 3,5 $\mathrm{GW}^{58}$. Warto nadmienić, że w 2013 roku łączne wynagrodzenie za doprowadzenie do sieci energii elektrycznej wyprodukowanej ze źródeł odnawialnych wyniosło 21,980 mln euro.

8 kwietnia 2014 roku rząd federalny przyjął projekt nowelizacji ustawy o odnawialnych źródłach energii, której celami było zahamowanie wzrostu cen energii przez zmniejszenie gwarantowanych cen dla energii ze źródeł odnawialnych, wprowadzenie corocznych limitów na budowę nowych instalacji produkujących energię elektryczną ze źródeł odnawialnych i przyspieszenie integracji odnawialnych źródeł energii z rynkiem energii. Planowane limity budowy nowych mocy miały ograniczyć budowę instalacji fotowoltaicznych do 2500 MW rocznie brutto, lądowych elektrowni wiatrowych do 2500 MW

58 Zob. H.-W. Schiffer, Energiemarkt Deutschland. Jahrbuch 2015, Köln 2014, s. 315-324. 
netto rocznie, elektrowni na biomasę do $100 \mathrm{MW}$ rocznie, a morskich elektrowni wiatrowych do $6500 \mathrm{MW}$ do 2020 roku i $15000 \mathrm{MW}$ do 2030 roku. Znowelizowana ustawa ułatwia rynkową integrację nowych instalacji odnawialnych źródeł energii poprzez obowiązkową sprzedaż bezpośrednią na rynku bieżącym, wstrzymanie systemu taryf gwarantowanych w okresie ujemnych cen energii i ustanowienie fazy pilotażowej dla aukcji obejmujących $400 \mathrm{MW}$ wolnostojących ogniw fotowoltaicznych. Ustawa zawiera warunki przyznawania ulg w opłatach za energię elektryczną dla przemysłu energochłonnego ${ }^{59}$. Rząd federalny uzasadniał przywileje dla wybranych przedsiębiorstw, szczególnie hut aluminium i stali, wymogami konkurencji na rynkach światowych. 8 kwietnia 2014 roku doszło do porozumienia Komisji Europejskiej i rządu federalnego w tym zakresie. Zmniejszono liczbę przedsiębiorstw korzystających z tańszej energii elektrycznej z 2100 do 1 600. Zgodnie z nowymi wytycznymi około 350 przedsiębiorstw musiało zwrócić skarbowi państwa ulgi, które były niezgodne z prawem UE, w wysokości $300 \mathrm{mln}$ euro. Nowelizacja ustawy EEG jest zgodna z wytycznymi Komisji w sprawie pomocy publicznej udzielanej przez państwa członkowskie sektorom energetyki i ochrony środowiska przedstawionymi 9 kwietnia 2014 roku. KE wyznaczyła 68 energochłonnych branż kwalifikujących się do otrzymywania ulg - warunkiem jest udział kosztów energii w kosztach produkcji powyżej 10\% oraz eksport produkcji poza Unię Europejską powyżej 10\% ${ }^{60}$.

23 lipca 2014 roku Komisja Europejska ogłosiła, że znowelizowana ustawa jest zgodna $\mathrm{z}$ unijnym prawem ${ }^{61}$. Niemcy zobowiązały się zapłacić karę w wysokości $50 \mathrm{mln}$ euro za to, że przez dwa lata utrzymywały regulacje niezgodne z prawem konkurencji Unii Europejskiej.

Postanowienia art. 107-109 TFUE określają zasady przyznawania przez państwa członkowskie UE pomocy publicznej. W art. 107 ust. 1 TFUE zawarto określenie pomocy publicznej, w którym nie wyjaśniono wprost czym jest pomoc publiczna, lecz wskazano, kiedy stosowanie środków pomocowych jest zakazane. Artykuł 107 ust. 2 TFUE przewiduje też, w jakich przypadkach udzielona pomoc publiczna jest zawsze zgodna $\mathrm{z}$ rynkiem wewnętrznym,

59 Szerzej: E. Reschke, dz. cyt.

60 Komunikat Komisji, Wytyczne w sprawie pomocy państwa na ochronę środowiska i cele zwiąane $z$ energia w latach 2014-2020 (2014/C 200/01), http://www.wfosgw.poznan. pl/pub/files/file/2014/09/wytyczne_w_sprawie_pomocy_panstwa_na_ochrone_srodowiska_i_cele_zwiazane_z_energia_w_latach_2014-2020.pdf (dostęp: 20.06.2016).

${ }^{61}$ Staatliche Beihilfen: EU-Kommission genehmigt Gesetz über erneuerbare Energien, Europäische Kommission, Pressemitteilung, Brüssel, 23. Juli 2014, http://europa.eu/ rapid/press-release_IP-14-867_de.htm (dostęp: 20.06.2016). 
a art. 107 ust. 3 TFUE określa, w jakich przypadkach taka pomoc może zostać uznana za zgodną z rynkiem wewnętrznym.

18 grudnia 2013 roku Komisja wszczęła formalne postępowanie wyjaśniające, czy środki zawarte w znowelizowanej ustawie z 2012 roku i zrealizowane $\mathrm{w}$ formie pomocy na korzyść energii elektrycznej ze źródeł odnawialnych oraz odbiorców energochłonnych są zgodne z przepisami dotyczącymi udzielenia pomocy publicznej na podstawie art. 108 pkt. 2 TFUE $^{62}$.

W grudniu 2011 roku Bund der Energieverbraucher (związek odbiorców energii elektrycznej) złożył do Komisji Europejskiej skargę administracyjną, w której podniósł, że pewne środki przewidziane w noweli ustawy z 2012 roku stanowiły pomoc niezgodną z rynkiem wewnętrznym. Przedmiotem badania Komisji Europejskiej były trzy elementy systemu wsparcia dla odnawialnych źródeł energii: rozbudowany system taryf gwarantowanych na zakup energii elektrycznej wyprodukowanej ze źródeł odnawialnych, ich wysokość dla poszczególnych źródeł wytwórczych i wysokość dodatków za elastyczną produkcję energii elektrycznej oraz ulgi w opłatach na odnawialne źródła energii dla przedsiębiorstw energochłonnych i tzw. „przywilej dla zielonej energii” (Grünstromprivileg, par. 39 ustawy o odnawialnych źródłach energii), czyli system ulg podatkowych polegający na zapewnieniu częściowego zwolnienia z dopłaty do odnawialnych źródeł energii, gdy dostarczona przez sprzedawców ilość energii elektrycznej pochodzi w 50\% z rodzimych elektrowni, które użytkują odnawialne źródła energii i są czynne od co najwyżej 20 lat, oraz ulgi dla energochłonnego przemysłu. W ocenie Komisji Europejskiej powyższe elementy niemieckiego systemu wsparcia były sprzeczne z polityką konkurencji UE. Komisja Europejska argumentowała, że producenci energii elektrycznej ze źródeł odnawialnych byli faworyzowani poprzez to, że w ramach wynagrodzenia za doprowadzenie energii elektrycznej do sieci uzyskiwali wyższą cenę za swoją energię elektryczną niż otrzymaliby na rynku hurtowym (za który Komisja Europejska przyjęła EPEX Spot SE). To samo odnosiło się do bezpośredniego wprowadzenia na rynek, który dawał operatorom instalacji możliwość uzyskiwania wyższej ceny za swoją energię elektryczną niż cena rynkowa. „Nadbudowa” wobec ceny rynkowej wyniosła

62 Staatliche Beihilfe SA.33995 (2013/C) (ex 2013/NN) - Deutschland, Förderung der Stromerzeugung aus erneuerbaren Energien und Begrenzung der EEG-Umlage für energieintensive Unternehmen, Europäische Kommission, Brüssel, 18.12.2014, C(2013) 4424 final, http://www.bafa.de/bafa/de/energie/besondere_ausgleichsregelung_eeg/publikationen/bmwi/131219_beschluss_der_kommission_staatliche_beihilfe.pdf (dostęp: 26.06.2016). 
według obliczeń Komisji w 2012 roku 16,5 mld euro. Poprzez „przywilej dla zielonej energii” (jako formy bezpośredniego wprowadzania na rynek) pośrednio wsparcie zyskali także operatorzy instalacji, ponieważ przedsiębiorstwa zaopatrzenia $\mathrm{w}$ energię elektryczną na podstawie ulgi w dopłacie do odnawialnych źródeł energii mogłyby płacić dostawcom takiej energii elektrycznej cenę wyższą niż cena rynkowa. Zatem regulacje faworyzowały tylko producentów energii elektrycznej pochodzącej ze źródeł odnawialnych ${ }^{63}$.

28 lutego 2014 roku rząd federalny wniósł skargę do Trybunału Sprawiedliwości Unii Europejskiej przeciwko postępowaniu rozpoczętemu przez Komisję. Z kolei w listopadzie 2014 roku Komisja Europejska orzekła, że mechanizmy zawarte $\mathrm{w}$ ustawie z 2012 roku zawierają elementy pomocy publicznej $^{64} .2$ lutego 2015 roku Niemcy wniosły do Trybunału Sprawiedliwości UE skargę o stwierdzenie nieważności zaskarżonej decyzji Komisji Europejskiej. Niemcy stały na stanowisku, że zaskarżona decyzja stanowi naruszenie art. 107 ust. 1 TFUE w zakresie, w jakim Komisja miała dopuścić się różnych oczywistych błędów w ocenie w ramach swojej analizy roli państwa w funkcjonowaniu ustawy z 2012 roku.

Trybunał Sprawiedliwości Unii Europejskiej w orzeczeniu z 10 maja 2016 roku stwierdził, że Komisja Europejska słusznie uznała w zaskarżonej decyzji, iż ustawa z 2012 roku wiąże się z użyciem zasobów państwowych w rozumieniu art. 107 ust. 1 TFUE. Za pomoc publiczną zostały uznane zwolnienia z ponoszenia części tych kosztów, z których mogą korzystać wybrani odbiorcy przemysłowi. Ustawa zapewniała producentom energii ze źródeł odnawialnych ceny za energię wyższe niż rynkowe dzięki mechanizmowi opłaty na odnawialne źródła energii, której koszty są przenoszone finalnie na odbiorców. Trybunał podkreślił również, że ustawa częściowo zwalniała odbiorców przemysłowych z opłaty na odnawialne źródła energii, co miało na celu obniżenie ich kosztów i utrzymanie międzynarodowej konkurencyjności ${ }^{65}$.

Warto nadmienić, że system wsparcia rozwoju odnawialnych źródeł energii w Niemczech był już przedmiotem badania przez Komisję Europejską. Dotyczyło ono wspomnianej już ustawy z roku 2000. Ostatecznie 22 maja 2002 roku Komisja Europejska wydała decyzję, zgodnie z którą system

63 Szerzej: E. Reschke, $d z$. cyt.

64 Beschluss (EU) 2015/1585 der Kommission vom 25. November 2014 über die Beihilferegelung SA.33995 (2013/C) (ex 2013/NN) [Deutschlands zur Förderung erneuerbaren Stroms und stromintensiver Unternehmen], http://eur-lex.europa.eu/legal-content/DE/ALL/?uri=CELEX:32015D1585 (dostęp: 24.06.2016).

65 Urteil des Gerichts (Dritte Kammer), 10. Mai 2016 in der Rechtssache T-47/15, https:// www.clearingstelle-eeg.de/files/EuG_160510_1.pdf (dostęp: 23.06.2016). 
wsparcia produkcji energii elektrycznej ze źródeł odnawialnych zapisany w ustawie z roku 2000 nie stanowił pomocy publicznej ${ }^{66}$.

Innym przykładem jest postępowanie przed Trybunałem, które zostało wszczęte w związku ze skargą niemieckiego przedsiębiorstwa PreussenElektra AG domagającego się zwrotu dodatkowych kosztów poniesionych w związku z wynikającym z prawa obowiązkiem zakupu energii elektrycznej wytworzonej ze źródeł odnawialnych. System wsparcia dla odnawialnych źródeł energii (tj. system cen gwarantowanych) nakładał na dystrybutorów energii elektrycznej pochodzącej ze źródeł odnawialnych obowiązek zakupu energii od określonych producentów po ustalonej przez państwo cenie, wyższej od ceny rynkowej. Według PreussenElektra AG takie uregulowania należało zakwalifikować jako pomoc publiczną. W wyroku z 13 marca 2001 roku Trybunał stwierdził, że mechanizm taki nie stanowił pomocy państwa w rozumieniu TFUE, gdyż nie obejmował transferów zasobów państwowych, mimo iż powstał z inicjatywy państwa, a środki te pochodziły ze źródeł prywatnych. Przedsiębiorstwa prywatne nie były upoważnione przez dane państwo członkowskie do zarządzania zasobami państwowymi, lecz były jedynie zobowiązane do zakupu przy pomocy własnych środków finansowych. W ten sposób fundusze rozpatrywane w sprawie nie mogły być uznane za zasoby państwa, ponieważ nie były w żadnej chwili pod kontrolą państwową i nie istniał żaden ustanowiony i regulowany przez państwo członkowskie mechanizm rekompensaty dodatkowych kosztów wynikających z tego obowiązku zakupu, za pomocą którego państwo gwarantowało tym podmiotom prywatnym całkowite pokrycie dodatkowych kosztów ${ }^{67}$.

\section{Wnioski}

Europeizacja koncentruje się na adaptacji do procesów integracyjnych mechanizmów, procesów i instytucji w państwach członkowskich UE, przy czym sama adaptacja zakłada istnienie określonych reguł, w oparciu o które przyjęte na poziomie ponadnarodowym rozwiązania implementowane są na pozostałych poziomach. Niemniej jednak wraz z niewielką efektywnością polityki na poziomie unijnym coraz częstsze są jednostronne i niezależne od siebie działania państw członkowskich UE, a zwłaszcza Niemiec, których

66 Europäische Kommission, Beihilfeverfahren NN 27/2000 - Deutschland EEG 2000 vom 22.05.2002, http://ec.europa.eu/competition/state_aid/cases/138917/138917_410173_ 26_2.pdf (dostęp: 20.06.2016).

67 Urteil des Gerichtshofes 13. März 2001 in der Rechtssache C-379/98, https://www.clearingstelle-eeg.de/files/private/active/0/eugh_010313_C-379-98.pdf (dostęp: 20.06.2016). 
celem jest m.in. zapobieganie pogarszaniu się sytuacji kluczowych sektorów gospodarki, zarówno branż energochłonnych, jak i sektora energetycznego.

Rezultaty europeizacji polityki energetycznej Niemiec są niejednoznaczne, zauważyć można duże różnice w odniesieniu do poszczególnych obszarów. Liberalizacja rynku energii elektrycznej i gazu ziemnego w UE stała się w drugiej połowie lat 90. ubiegłego wieku i na początku XXI wieku przedmiotem sporów między UE a Niemcami. Niemniej jednak Komisji Europejskiej udało się doprowadzić do stopniowych zmian w niemieckiej polityce energetycznej, w tym utworzenia urzędu regulacji i większej konkurencji na rynku energetycznym (energii elektrycznej i gazu ziemnego). Postępowania Komisji Europejskiej wobec niemieckich koncernów energetycznych miały istotne znaczenie dla zwalczania porozumień szkodliwych dla konkurencji na rynku energetycznym UE. W przypadku tzw. trzeciego pakietu energetycznego kwestią zasadniczą stał się rozdział pionowo zintegrowanych przedsiębiorstw energetycznych, który Komisja Europejska postrzegała jako centralny instrument służący zwiększeniu konkurencji na rynku energii oraz wzrostowi inwestycji w infrastrukturę przesyłową. Stąd też istotne były zobowiązania koncernów E.ON, RWE i Vattenfall do sprzedaży swoich sieci przesyłowych.

Rozwój odnawialnych źródeł energii stanowi stanowi jeden z zasadniczych celów polityki energetycznej (i klimatycznej) Unii Europejskiej, jak również transformacji energetycznej w Niemczech. Zobowiązania jakie zostały określone w tym zakresie przez Niemcy wykraczają jednak znacznie poza unijny poziom. Niemniej jednak działania podejmowane przez Niemcy mające na celu zwiększenie wykorzystania odnawialnych źródeł energii i mechanizm wsparcia ich rozwoju były przedmiotem sporów z Komisją Europejską i uruchomienia przez nią postępowania sprawdzającego udzielanie pomocy publicznej niezgodnej z rynkiem wewnętrznym UE. W najbliższym czasie należy oczekiwać propozycji zmian systemu wsparcia rozwoju odnawialnych źródeł energii w Niemczech, których istota powinna sprowadzać się do ograniczenia subsydiowania odnawialnych źródeł energii w obecnej skali.

\section{Zusammenfassung}

Das Ziel des Artikels ist es, Probleme der Europäisierung der Energiepolitik in Deutschland an der Jahrhundertwende synthetisch darzustellen. Die Analyse umfasst die Frage nach der deutschen Gesetzgebung sowie EU-Vorschriften im Prozess der Liberalisierung, Anpassung und Schaffung des Energiebinnenmarktes der EU im Hinblick auf die Verfahren der Europäischen Kommission gegen Deutschland. Darüber hinaus werden auch das deutsche Energieversorgungsunternehmen und das Problem der Unterstützung der 
Entwicklung der erneuerbaren Energien in Deutschland im Rahmen der EU-Lösungen erörtert. Die Analyse basiert auf den verfügbaren Quellen und Literatur wie auch auf eigenen Studien der Autorin.

\section{Bibliografia}

ANGENENDT N., Unbundling im internationalen Vergleich: Rechtliche Entwicklungen in Deutschland im Zuge der Liberalisierung des Strombinnenmarktes im Vergleich zu Österreich (Studien zur Rechtswissenschaft), Hamburg 2007.

BÖRZEL T., Institutional Adaptation to Europeanization in Germany and Spain, „Journal of Common Market Studies” 1999, t. 37, nr 4.

CIANCIARA A.K., Wzory europeizacji zewnętrznej: mechanizmy, uwarunkowania, rezultaty, „Studia Europejskie” 2013, nr 3.

DYREKTYWA 2003/54/WE Parlamentu Europejskiego i Rady z dnia 26 czerwca 2003 r. dotyczaca wspólnych zasad rynku wewnętrznego energii elektrycznej i uchylająca dyrektywę 96/92/WE (Dz. Urz. UE L 176 z 15.07.2003).

DYREKTYWA 2003/55/WE Parlamentu Europejskiego i Rady z dnia 26 czerwca 2003 r. dotyczaca wspólnych zasad rynku wewnętrznego gazu ziemnego i uchylająca dyrektywę 98/30/WE (Dz. Urz. UE L 176 z 15.07.2003).

DYREKTYWA 96/92/WE Parlamentu Europejskiego i Rady z dnia 19 grudnia 1996 r. dotycząca wspólnych zasad rynku wewnętrznego energii elektrycznej (Dz. Urz. WE L 27 z 30.01.1997).

DYREKTYWA 98/30/WE Parlamentu Europejskiego i Rady z dnia 22 czerwca 1998 r. dotyczaca wspólnych zasad w odniesieniu do rynku wewnętrznego gazu ziemnego (Dz. Urz. WE L 204 z 21.07.1998).

ERNEUERBARE-ENERGIEN-GESETZ vom 29. März 2000, BGBl., cz. I, s. 305.

GESETZ über die Einspeisung von Strom aus erneuerbaren Energien in das öffentliche Netz vom 7. Dezember 1990 (Stromeinspeisungsgesetz), BGBl., cZ. I, s. 2633.

GESETZ zur Umsetzung der Richtlinie 2009/28/EG zur Förderung der Nutzung von Energie aus erneuerbaren Quellen, vom 12. April 2011, BGBl. 2011, cz. 1, nr 17.

HEUTERKES M., JANSSEN M. (red.), Die Regulierung von Gas- und Strommärkten in Deutschland, Westfälische Wilhelms-Universität Münster, „Beiträge aus der angewandten Wirtschaftsforschung” 2008, nr 29.

HOFMAN M., Regulierung und Wettbewerb. Koordinationsmechanismen im europäischen Energiesektor, Zürich 2013.

INFORMACJA prasowa Komisji z 12 czerwca 2008 r., IP/08/394.

KOMMISSION, Entscheidung vom 18. März 2009, Sache COMP/39.402 - Gasmarktabschottung durch RWE. 
KOMMISSION, Entscheidung vom 8. Juli 2009, Sache COMP/39.401 - E. N/ GDF.

KREIS C., Deregulierung und Liberalisierung der europaeischen Elektrizitaetswirtschaft: theoretische und empirische Befunde, Baden-Baden 2004.

LADRECH R., Europeanization of Domestics Politics and Institutions: The case of France, „Journal of Common Market Studies” 1994, t. 32, nr 1.

MOLO B., Polityka bezpieczeństwa energetycznego Niemiec w XXI wieku, Kraków 2013.

OLBRICHT T., Netzzugang in der deutschen Gaswirtschaft, Essen 2008.

RADAELLI C.M., The Europeanization of Public Policy, [w:] K. Featherstone, C.M. Rdaelli (red.), The Politics of Europeanization, Oxford 2003.

RADAELLI C.M., Whither Europeanization? Concept stretching and substantive change, „European Integration on-line papers” 2000, t. 4, nr 8.

RENZ T., Vom Monopol zum Wettbewerb. Die Liberalisierung der deutschen Stromwirtschaft, Opladen 2001.

RESCHKE E., Das Erneuerbare-Energien-Gesetz (EEG) und das europäische Beihilferecht, Marburg 2014.

ROZPORZACDZENIE (WE) nr 1228/2003 Parlamentu Europejskiego i Rady $z$ dnia 26 czerwca 2003 r. w sprawie warunków dostępu do sieci $w$ odniesieniu do transgranicznej wymiany energii elektrycznej (Dz. Urz. UE L 176 z 15.07.2003).

SCHIFFER H.-W., Energiemarkt Deutschland, Köln 2005.

SCHIFFER H.-W., Energiemarkt Deutschland. Jahrbuch 2015, Köln 2014.

TWELEMANN S., Stromwirtschaft im Spannungsfeld zwischen Wettbewerb und Klimapolitik. Eine Untersuchung am Beispiel des deutschen Strommarktes, Frankfurt am Main [u.a.] 2006.

bafa.de

dejure.org

eur-lex.europa.eu

europa.eu

gesetzgebung.beck.de

orka.sejm.gov.pl

www.bmwi.de

www.bundesregierung.de

www.clearingstelle-eeg.de

www.jusmeum.de

www.pga.org.pl

www.wfosgw.poznan.pl 